\title{
Characterization of the Crystal Structure of Sesame Seed Cake Burned by Nd: YAG Laser
}

\author{
Muna A. Pn Gawbahi,2, Abdelrahman A. Elbadawi ${ }^{2,3}$, Yousef A. Alsabah ${ }^{2,4^{*}}$, Mohammed U. Orsod \\ Ali A. S. Marouf6
}

${ }^{1}$ Physics Department, Faculty of Education-Seyoun, Hadhramout University, Hadhramout, Yemen

${ }^{2}$ Department of Physics, Faculty of Science and Technology, Al Neelain University, Khartoum, Sudan

${ }^{3}$ Faculty of Basic Studies, Future University, Khartoum, Sudan

${ }^{4}$ Department of Physics, Faculty of Education and Applied Science, Hajjah University, Hajjah, Yemen

${ }^{5}$ College of Science, Sudan University of Science and Technology, Khartoum, Sudan

${ }^{6}$ Institute of Laser, Sudan University of Science and Technology, Khartoum, Sudan

Email: ${ }^{\star}$ y.a.alsabah@gmail.com

How to cite this paper: Gawbah, M.A.P., Elbadawi, A.A., Alsabah, Y.A., Orsod, M.U. and Marouf, A.A.S. (2018) Characterization of the Crystal Structure of Sesame Seed Cake Burned by Nd: YAG Laser. Journal of Materials Science and Chemical Engineering, 6, 121-131.

https://doi.org/10.4236/msce.2018.64013

Received: February 22, 2018

Accepted: April 24, 2018

Published: April 27, 2018

Copyright () 2018 by authors and Scientific Research Publishing Inc. This work is licensed under the Creative Commons Attribution International License (CC BY 4.0).

http://creativecommons.org/licenses/by/4.0/

\section{(c) (i) Open Access}

\begin{abstract}
This paper reports obtaining of useful and high-value materials from sesame seed cake (SSC). For this purpose, SSC sample was burned for $30 \mathrm{~s}$ using Nd: YAG laser with output power $60 \mathrm{~W}$. The products of this process and non-burned SSC were characterized by X-ray diffractometer (XRD), energy dispersive $\mathrm{X}$-ray (EDX) and Fourier transform infrared (FTIR) so as to investigate its crystal structure and chemical components. XRD results of the SSC before burning process showed amorphous silica, rhombohedral phase of carbon, monoclinic phase of aluminum chloride, the hexagonal phase of moissanite- $4 \mathrm{H}$, (yellow, black) and hexagonal phase of graphite- $2 \mathrm{H}, \mathrm{C}$ (black). While the results of the burned SSC sample showed that the burning process using the power of Nd: YAG laser cased in appearing of crystalline hexagonal phase for silica and Carbon Nitride and converting the rhombohedral phase of Carbon into hexagonal phase. FTIR showed a number of absorbance peaks assigned to silica.
\end{abstract}

\section{Keywords}

Crystal Structure, FTIR, Hexagonal Carbon, Laser-Based Combustion, Sesame Seed Cake, Sesame Oil Cake, Silica, XRD

\section{Introduction}

There are a large number of agricultural wastes and they have become an increasing concern in recent years, as they may cause significant environmental 
problems [1]. With appropriate techniques, agricultural wastes can be recycled to produce useful materials, the source of energy, chemical recovery, chemical or dye adsorption and natural fertilizer for crops [2]. Many investigations show that useful and high-value materials can be obtained from a cheap agricultural waste. For example, rice husk contains about $20 \%$ of ash which can be recovered as amorphous silica [3]. Many types of research relating to extraction silica from rice husk and rice straw have been reported [4] [5] [6] [7] [8]. Della et al. found the relative amount of silica was increased after burning out the carbonaceous material at different times and temperatures. A 95\% silica powder could be produced after heat-treating at $700^{\circ} \mathrm{C}$ for $6 \mathrm{~h} \mathrm{[4].} \mathrm{Singh} \mathrm{et} \mathrm{al.} \mathrm{discussed} \mathrm{synthesis} \mathrm{and}$ characterization of rice husk based nano-silica and reported the activated rice husk silica transforms into the crystalline product when burnt above $1000^{\circ} \mathrm{C}$ [9].

Also, in wheat husk there are two forms of silica after burning process, crystalline silica and/or amorphous silica [10]. Chen et al. prepared nano-silica from wheat straw through combustion and acid leaching [11], Naqvi et al. extracted amorphous silica from wheat husk by using $\mathrm{KMNO}_{4}$ [12], and Gawbah et al. used Nd: YAG laser to synthesis silica and some valuable materials from wheat bran [13].

Silica is one of the most important components and can be found in many applications such as biotechnology-related materials, medical-related materials [8], raw materials for cement industry [14]. Tailored materials composed of nanoparticles have potential for application in numerous technological fields [6].

In this study, we used sesame seed cake (SSC); it is the residue left after oil extraction which used as cattle feed [15] [16]. This residue can be recovered and value added [17]. We burned SSC by a $1.064 \mu \mathrm{m} \mathrm{Nd:} \mathrm{YAG} \mathrm{laser} \mathrm{with} 60 \mathrm{~W}$ output power for $30 \mathrm{~s}$. The advantage of Nd: YAG laser comes from its high gain and good thermal properties; it is the most important solid-state laser for scientific, medical, industrial, and military applications [18] [19]. The laser heat was used instead of the heat of the furnace in the burning of SSC and this method saved power, time and effort. Lasers have sufficiently high power with low divergence to be able to focus down to a desired size and to have enough power density to heat samples at high pressure; Lasers with high power stability and beam pointing stability are essential for producing a heating spot at steady temperature and at a constant position [20]. Silica $\left(\mathrm{SiO}_{2}\right)$ is a basic raw material that is widely used in electronics, ceramic, and polymer material industries. Due to their small-diameter, silica powders have many technological applications, such as thixotropic agents, thermal insulators, composite fillers, etc. [21]. Silica also has been used as a major precursor for a variety of inorganic and organometallic materials which have applications in synthetic chemistry as catalysts, and in thin films or coatings for electronic and optical materials [22] [23]. Carbon nitrides can applied in the field of catalysis, electrocatalysis, optoelectronics, sensors, separations and others [24].

Utilizing SSC in preparing silica, carbon nitrides and hexagonal carbon will 
decrease the cost of waste disposal and also convert this waste into value-added products. We studied SSC before and after burning process. The physical and chemical characterizations selected in this study included EDX, XRD, FTIR and Digital Microscope. The objective of the work is to obtain useful and valuable materials like silica and silicon nitride from SSC burned using Nd: YAG laser.

\section{Material and Method}

\subsection{Experimental}

SSC sample was collected from Omdurman, Sudan. It was washed with distilled water many times to remove adhering soil and other contaminants then dried at room temperature after that it was milled. One gram of the sample was placed into a high-temperature glass beaker (Schott Duran-Germany) and it was burned on the air by the heat of Nd: YAG laser (Dornier Medilas fiber to 5100) with an output power of $60 \mathrm{~W}$ for $30 \mathrm{~s}$. The laser beam was delivered by single mode fiber optic with diameter $125 \mu \mathrm{m}$, the distance between the sample and the end of the fiber optic was $1 \mathrm{~cm}$. Because of the small spot size of the laser beam, the process of burning was done point by point, the laser was fixed on a holder while the high-temperature glass beaker was rotated every $30 \mathrm{~s}$ carefully for approximately $5 \mathrm{~mm}$ see Figure 1, this step repeated many times before investigations for accuracy.

\subsection{Characterization}

Samples were examined before and after burning process by XRD (Shimadzu, MAX_X, XRD-7000) using $\mathrm{Cu} \mathrm{K}_{\alpha}$ with scanning speed of $1000^{\circ} / \mathrm{min}$ and the data were collected for $(2 \theta)$ range from $10^{\circ}$ to $80^{\circ}$ at a step size of $0.0002^{\circ}$. The samples were prepared by grinding carefully before XRD measurements by agate mortar for homogeneity. The data were analyzed by MDI jade 0.5 match program. EDX spectrometer (Shimadzu - EDX-8000) was employed to characterize burned and non-burned SSC samples. It was operated at $4 \mathrm{KV}$ to $50 \mathrm{KV}$ with

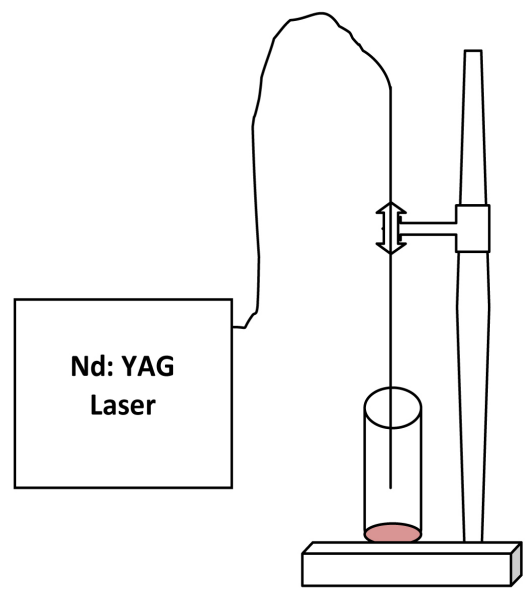

Figure 1. Schematic diagram of the experimental setup. 
software quantitative analysis. The chemical groups presented in burned and non-burned SSC samples were identified by the fourier transform infrared spectrometer. Samples were mixed with dry potassium bromide powder $\mathrm{KBr}$ with a ratio of 1:100, by applying sufficient pressure, the mixture was prepared to scan. FTIR spectra of samples were collected in the wavenumber range of (400 - 4000) $\mathrm{cm}^{-1}$ using (FTIR) spectrometer (Satellite FTIR 5000). Microscopic photograph of the burned SSC was done by (Digital Microscope 400X Digital Zoom).

\section{Results and Discussion}

\subsection{XRD Results}

The X-ray diffraction patterns were shown in Figure 2, it showed amorphous structure (including multi-phases) of the two samples, Figure 3 and Figure 4 showed the analyzed spectra for the SSC samples before and after burning process analyzed by MDI jade 0.5 match program, graphs showed the presence of the amorphous silica in the two samples, at the normal broad peak at $2 \theta=$ 21.7 - 21.8 for the samples before and after burning respectively. It also indicates that laser burning process is very effective to form the crystalline structure phases of silica. Therefore, some of the silica phases appeared in the samples. In non-burned SSC graph; the phases peaks were appeared at $2 \theta=15.009$ refer to rhombohedral carbon $\mathrm{C}$ (Transparent) phase, at $2 \theta=24.484$ refer aluminum chloride acetate $\mathrm{C}_{10} \mathrm{H}_{15} \mathrm{~A}_{12} \mathrm{ClO}_{10}$, at $2 \theta=30.159$ refer to a monoclinic aluminum chloride hydroxide hydrate $\mathrm{Al}_{10} \mathrm{C}_{13}(\mathrm{OH})_{27} ! 13 \mathrm{H}_{2} \mathrm{O}$, at $2 \theta=38.234$ refer to hexagonal moissanite- $4 \mathrm{H}$, synSiC (yellow, black) and at $2 \theta=77.457$ refer to hexagonal graphite-2H C(black). Different phases were appeared after burning

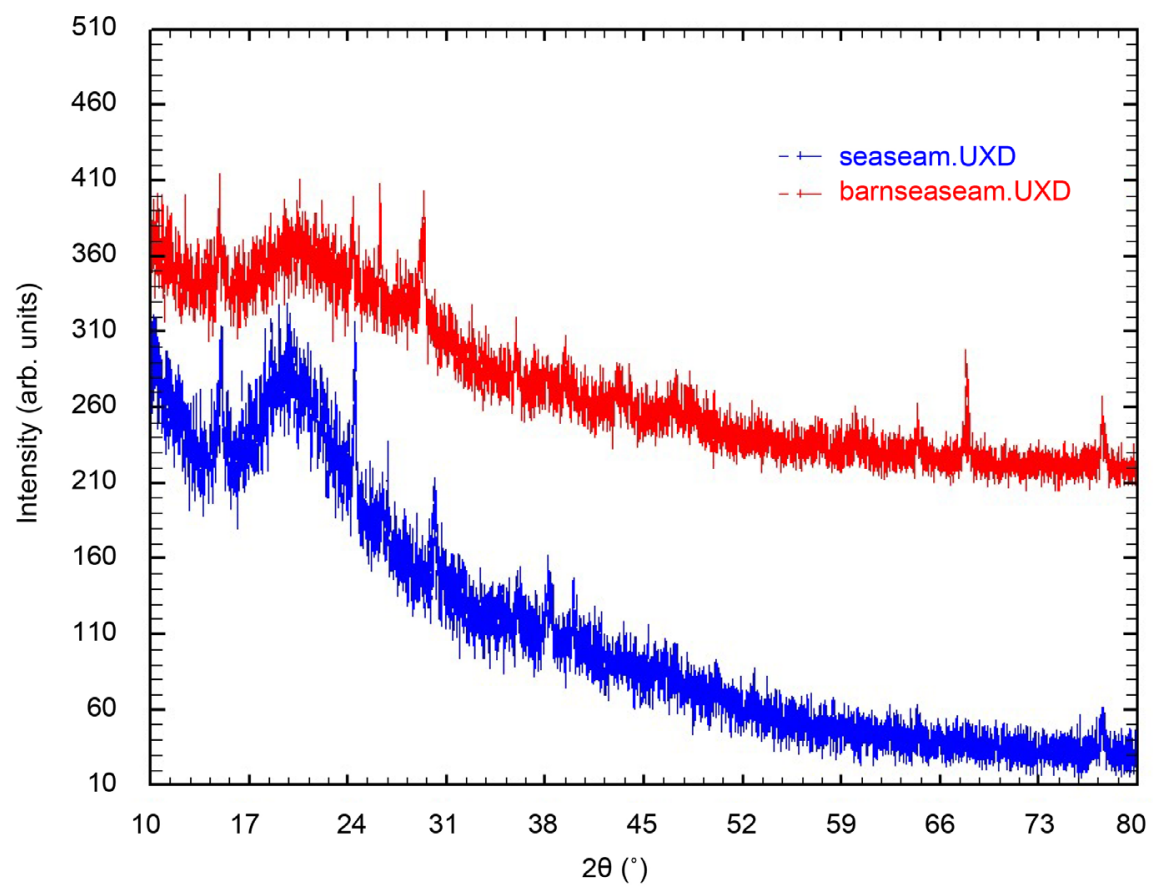

Figure 2. X-ray powder diffraction patterns of 1-nature, 2-burned SSC sample. 


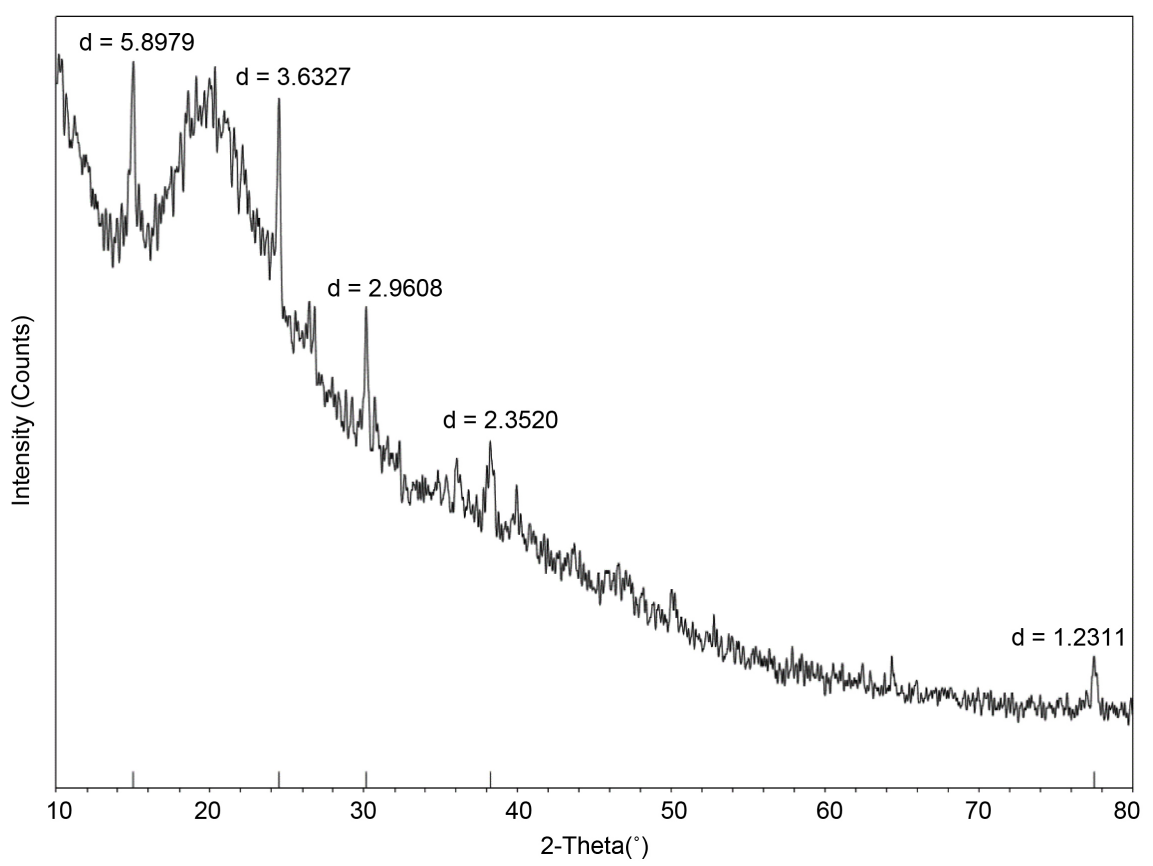

Figure 3. X-ray powder diffraction of nature SSC.

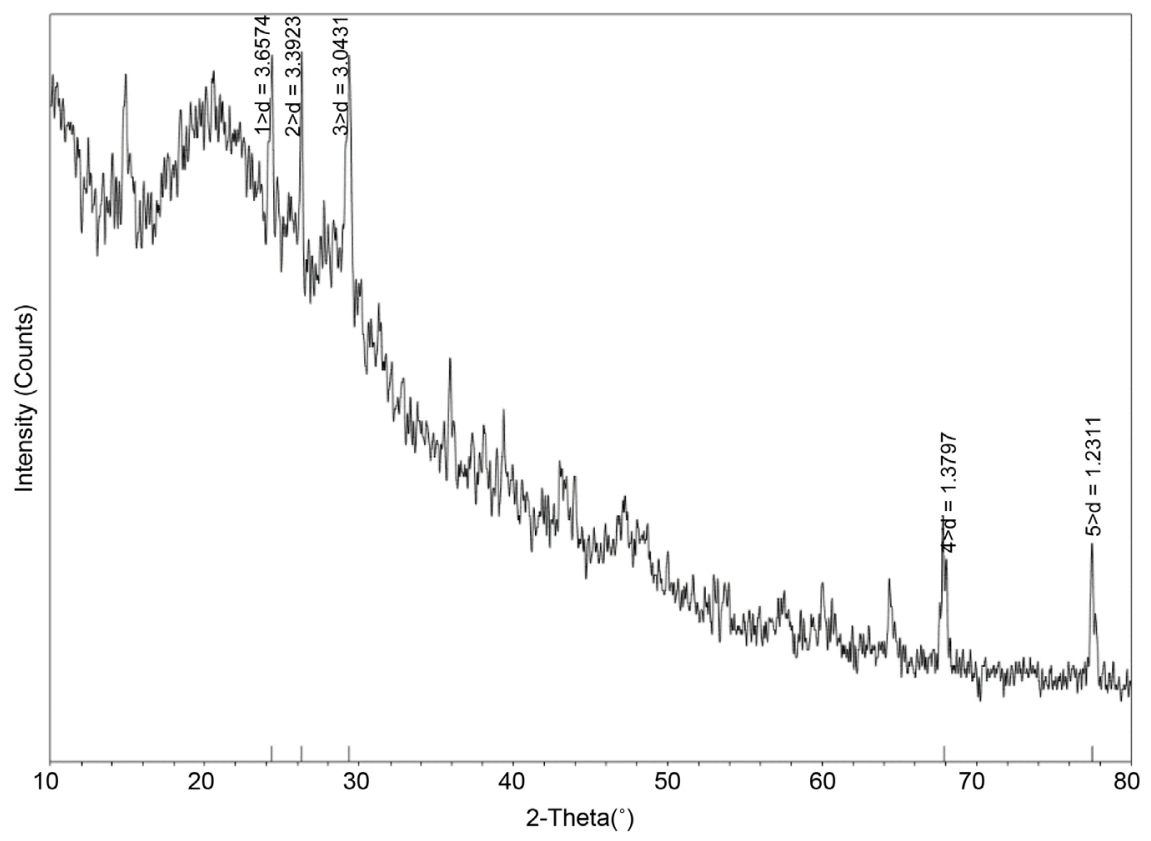

Figure 4. X-ray powder diffraction of burned SSC.

process that shown at $2 \theta=29.325$ refer to hexagonal carbonate $(\mathrm{C})$ phase, at $2 \theta=$ 77.462 refer to hexagonal carbon nitride $(\mathrm{CN})$ phase, at $2 \theta=24.316$ refer to orthorhombic silicon oxide, at $2 \theta=26.249$ this peak refer to hexagonal silicon oxide $\mathrm{SiO}_{2}$ and at $2 \theta=67.876$ refer to hexagonal silicon oxide. That also shown the peaks intensity and appearance was obtained with burning process. Table 1 and Table 2 showed the details of the XRD results. Digital microscope image in Figure 5 confirms the presence of white silica. 
Table 1. X-ray diffraction parameters of SSC.

\begin{tabular}{|c|c|c|c|c|c|c|c|}
\hline 2-Theta & $\mathrm{d}(\mathrm{A})$ & Height & Area & $\mathrm{I} \%$ & FWHM & $\begin{array}{c}\text { Crystal } \\
\text { structure }\end{array}$ & Phase \\
\hline 15.009 & 5.8979 & 77 & 2712 & 100.0 & 0.428 & Rhombohedral & $\begin{array}{c}\text { Carbon } \\
\text { C (Transparent) }\end{array}$ \\
\hline 24.484 & 3.6327 & 84 & 1983 & 73.1 & 0.287 & Unknown & $\begin{array}{l}\text { Aluminum Chloride Acetate } \\
\qquad \mathrm{C}_{10} \mathrm{H}_{15} \mathrm{Al}_{2} \mathrm{ClO}_{10}\end{array}$ \\
\hline 30.159 & 2.9608 & 59 & 1913 & 70.5 & 0.394 & Monoclinic & $\begin{array}{l}\text { Aluminum Chloride } \\
\text { Hydroxide Hydrate } \\
\mathrm{Al}_{10} \mathrm{Cl}_{3}(\mathrm{OH})_{27} \mathrm{H}_{2} \mathrm{O}\end{array}$ \\
\hline 38.234 & 2.3520 & 37 & 1394 & 51.4 & 0.458 & Hexagonal & $\begin{array}{l}\text { Moissanite-4H, syn } \\
\text { SiC (Yellow, black) }\end{array}$ \\
\hline 77.467 & 1.2311 & 23 & 781 & 28.8 & 0.413 & Hexagonal & $\begin{array}{c}\text { Graphite-2H } \\
\text { C (Black) }\end{array}$ \\
\hline
\end{tabular}

Table 2. X-ray diffraction parameters of burned SSC.

\begin{tabular}{|c|c|c|c|c|c|c|c|}
\hline 2-Theta & $\mathrm{d}(\mathrm{A})$ & Height & Area & $\mathrm{I} \%$ & FWHM & Crystal structure & Phase \\
\hline 24.316 & 3.6574 & 49 & 1365 & 66.9 & 0.339 & Orthorhombic & $\begin{array}{l}\text { Silicon oxide } \\
\mathrm{Si}_{64} \mathrm{O}_{128}\end{array}$ \\
\hline 26.249 & 3.3923 & 35 & 768 & 37.6 & 0.176 & Hexagonal & $\begin{array}{l}\text { Silicon oxide } \\
\qquad \mathrm{SiO}_{2}\end{array}$ \\
\hline 29.325 & 3.0431 & 61 & 2041 & 100.0 & 0.407 & Hexagonal & Carbon $(\mathrm{C})$ \\
\hline 67.876 & 1.3797 & 27 & 1066 & 52.2 & 0.480 & Hexagonal & $\begin{array}{c}\text { Quartz, syn } \\
\mathrm{SiO}_{2} \text { (White) }\end{array}$ \\
\hline 77.462 & 1.2311 & 37 & 1115 & 54.6 & 0.366 & Hexagonal & $\begin{array}{c}\text { Carbon Nitride } \\
\qquad \mathrm{CN}_{\mathrm{x}}\end{array}$ \\
\hline
\end{tabular}

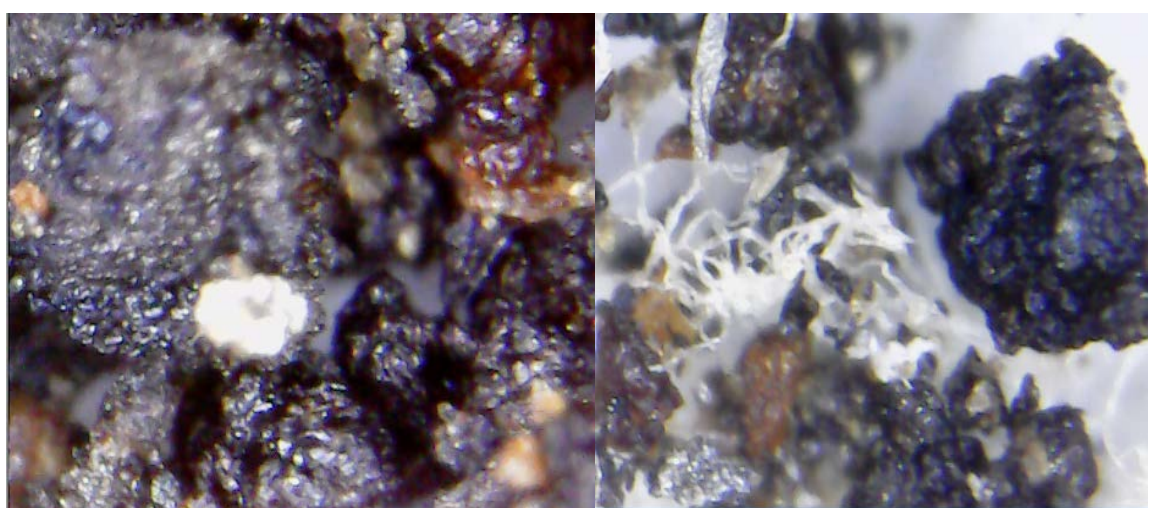

Figure 5. Microscopic photograph of the burned SSC (400× Digital Zoom).

\subsection{FTIR Analysis}

FTIR spectra were investigated for the burned and non-burned SSC samples that showed in Figure 6 and Table 3. The absorbance peak at $3430 \mathrm{~cm}^{-1}$ was due to the adsorbed water in the SSC samples after and before burning process, also that maybe refer to the $\mathrm{OH}$ stretching mode [11] [13]. The peak around 2926.55 $\mathrm{cm}^{-1}$ may be assigned to the asymmetric and symmetric vibrations of $\mathrm{C}-\mathrm{H},[25]$. 


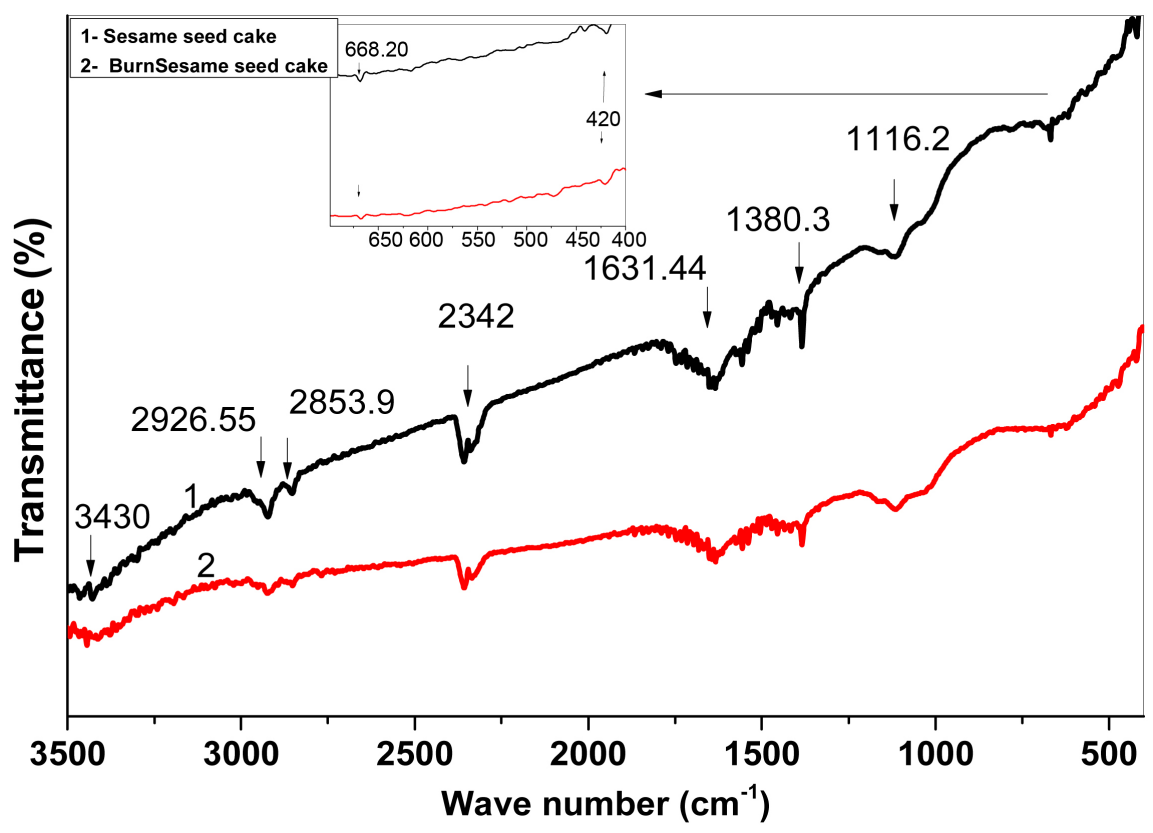

Figure 6. FTIR transmittance of SSC samples before and after burning process.

Table 3. FTIR Results of samples.

\begin{tabular}{ccc}
\hline $\begin{array}{c}\text { Absorption Peak } \\
\text { Position }\left(\mathrm{cm}^{-1}\right)\end{array}$ & Function group/modes of vibration & reference \\
\hline 3430 & OH stretching and vibration & {$[11][13]$} \\
2926.55 & the asymmetric and symmetric vibrations of C-H & {$[25]$} \\
2853.9 & stretching vibration C-H & {$[26]$} \\
2342 & $-\mathrm{C} \equiv \mathrm{N}-($ Nitrites) and $-\mathrm{C} \equiv \mathrm{C}-$ (Alkynes) compounds & {$[13][28]$} \\
1631.44 & the aromatic stretching & {$[11][13]$} \\
1380.3 & stretching vibration C-N & {$[26][28]$} \\
1116.2 & the Si-O-Si anti-symmetric stretching mode & {$[3][13]$} \\
$668.20-420$ & to siloxane bonds (Si-O-Si) & {$[11][13][29]$} \\
& stretching and bending vibrations & \\
\hline
\end{tabular}

The peak at $2853.9 \mathrm{~cm}^{-1}$ attributed to stretching vibration $\mathrm{C}-\mathrm{H}$ [26]. The absorbance peak around $2342 \mathrm{~cm}^{-1}$ obtained to $-\mathrm{C} \equiv \mathrm{N}-$ (Nitrites) and $-\mathrm{C} \equiv \mathrm{C}-$ (Alkynes) compounds [13] [27]. The peak near $1631.44 \mathrm{~cm}^{-1}$ assigned to the aromatic stretching in SSC structure [11] [13] [23]. The peak at $1380.3 \mathrm{~cm}^{-1}$ attributed to stretching vibration C-N [26]. The peak around $1116.2 \mathrm{~cm}^{-1}$ was due to the Si-O-Si asymmetric and symmetric stretching modes [3] [13]. The peaks around (668.20 and 420$) \mathrm{cm}^{-1}$ correspond to siloxane bonds (Si-O-Si) stretching and bending vibrations [11] [24] [13].

\subsection{EDX Results}

The EDX result was investigated using (Shimadzu, EDX-8000), Table 4 showed the weight of the elements in the samples of SSC before and after burning re- 
spectively. The X-ray passed through particles of the samples SSC to detect the presence of element especially the concentration of the carbonate, that noticed It was observed that the concentration of elements in the sample increases after burning for the carbon element shown in Figure 7, this is because a quantity of carbon evaporates in the form of carbon dioxide during combustion.

Table 4. EDX result of samples.

\begin{tabular}{ccc}
\hline Elements & Sesame seed cake (\%) & Burned Sesame seed cake (\%) \\
\hline $\mathrm{Ca}$ & 1.759 & 5.476 \\
$\mathrm{~K}$ & 1.381 & 3.770 \\
$\mathrm{~S}$ & 0.517 & 0.517 \\
$\mathrm{P}$ & 0.511 & 1.554 \\
$\mathrm{Si}$ & 0.116 & 0.269 \\
$\mathrm{Mg}$ & 0.071 & 0.206 \\
$\mathrm{Fe}$ & 0.032 & 0.119 \\
$\mathrm{Zn}$ & 0.016 & 0.041 \\
$\mathrm{Ag}$ & 0.014 & 0.000 \\
$\mathrm{Mn}$ & 0.009 & 0.031 \\
$\mathrm{Sr}$ & 0.009 & 0.021 \\
$\mathrm{Ti}$ & 0.008 & 0.005 \\
$\mathrm{Cu}$ & 0.005 & 0.014 \\
$\mathrm{Br}$ & 0.001 & 0.002 \\
$\mathrm{O}$ & 0.000 & 0.000 \\
$\mathrm{C}$ & 95.550 & 87.894 \\
\hline
\end{tabular}

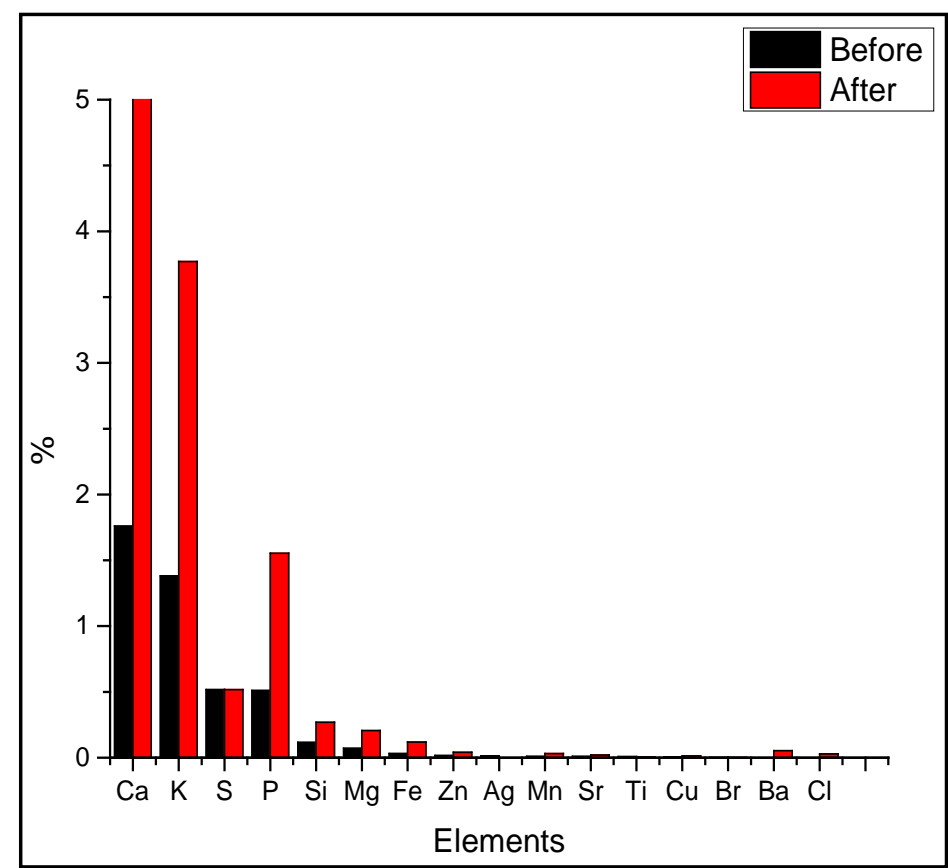

Figure 7. EDX result comparison between samples. 


\section{Conclusion}

Sesame seed cake (SSC) has silica contents which can be utilized to produce various useful materials. The possibility of producing silica and silicon carbide from SSC was achieved in this study by burning it by Nd: YAG laser. XRD results of the SSC before burning process showed amorphous silica, the rhombohedral phase of carbon, monoclinic phase aluminium chloride, the hexagonal phase of moissanite- $4 \mathrm{H}$, synSiC (yellow, black) and hexagonal phase of graphite- $2 \mathrm{H}, \mathrm{C}$ (black). The obtained results showed that burning process using Nd: YAG laser cased in appearing of crystalline hexagonal phase for silica and carbon nitride and converting the rhombohedral phase of Carbon into hexagonal phase. FTIR showed a number of absorbance peaks assigned to silica.

\section{Acknowledgements}

First of all authors would like to express their heart full appreciation to almighty God. Secondly gratefully acknowledge Institute of Laser, Sudan University of Science and Technology, Khartoum, Sudan for supporting this work. Also, many thanks for Department of Laser at Al Neelain University for their effort in conducting FTIR test for our samples including calibration and operation of FTIR instrument.

\section{References}

[1] Zhang, Z., Gonzalez, A.M., Davies, E.G. and Liu, Y. (2012) Agricultural Wastes. Water Environment Research, 84, 1386-1406. https://doi.org/10.2175/106143012X13407275695193

[2] Eshenaur, W., Collins, E., Goodrich, P.R. and Wulfe, M. (1984) Understanding Agricultural Waste Recycling: Volunteers in Technical Assistance.

[3] Mehta, A. and Ugwekar, R. (2015) Extraction of Silica and Other Related Products from Rice Husk. International Journal of Engineering Research and Applications, 5, 95-98.

[4] Della, V.P., Kühn, I. and Hotza, D. (2002) Rice Husk Ash as an Alternate Source for Active Silica Production. Materials Letters, 57, 818-821.

https://doi.org/10.1016/S0167-577X(02)00879-0

[5] Liou, T.-H. (2004) Preparation and Characterization of Nano-Structured Silica from Rice Husk. Materials Science and Engineering: A, 364, 313-323. https://doi.org/10.1016/j.msea.2003.08.045

[6] de Sousa, A.M., Visconte, L., Mansur, C. and Furtado, C. (2009) Silica Sol Obtained from Rice Husk Ash. 3, 321-326.

[7] Ghorbani, F., Sanati, A.M. and Maleki, M. (2015) Production of Silica Nanoparticles from Rice Husk as Agricultural Waste by Environmental Friendly Technique. Environmental Studies of Persian Gulf, 2, 56-65.

[8] Nandiyanto, A., Rahman, T., Fadhlulloh, M., Abdullah, A., Hamidah, I. and Mulyanti, B. (eds.) (2016) Synthesis of Silica Particles from Rice Straw Waste Using a Simple Extraction Method. IOP Conference Series: Materials Science and Engineering, 128, 12040. https://doi.org/10.1088/1757-899X/128/1/012040

[9] Singh, D., Kumar, R., Kumar, A. and Rai, K. (2008) Synthesis And characterization 
of Rice Husk Silica, Silica-Carbon Composite and H3PO4 Activated Silica. Cerâmica, 54, 203-212. https://doi.org/10.1590/S0366-69132008000200011

[10] Naqvi, H., Saeed, A., Umair, A. and Tajwar, S. (2011) Precipitated Silica from Wheat Husk. Journal of Pakistan Institute of Chemical Engineers, 39, 51-54.

[11] Chen, H., Wang, F., Zhang, C., Shi, Y., Jin, G., Yuan, S. (2010) Preparation of Nano-Silica Materials: The Concept from Wheat Straw. Journal of Non-Crystalline Solids, 356, 2781-2785. https://doi.org/10.1016/j.jnoncrysol.2010.09.051

[12] Naqvi, J., Shah, F. and Mansha, M. (2011) Extraction of Amorphous Silica from Wheat Husk by Using KMnO4. Journal of Faculty of Engineering \& Technology, 18, 39-46.

[13] Gawbah, M.A.P., Marouf, A.A., Alsabah, Y.A., Orsod, M.U. and Elbadawi, A.A. (2017) Synthesis of Silica, Silicon Carbide and Carbon from Wheat Bran and Converting Its Crystal Structure Using Nd: YAG Laser. International Journal of Advanced in Physical Science, 4, 31-37.

[14] Habeeb, G.A. and Mahmud, H.B. (2010) Study on Properties of Rice Husk Ash and Its Use as Cement Replacement Material. Materials Research, 13, 185-190.

https://doi.org/10.1590/S1516-14392010000200011

[15] Suja, K., Jayalekshmy, A. and Arumughan, C. (2005) Antioxidant Activity of Sesame Cake Extract. Food Chemistry, 91, 213-219. https://doi.org/10.1016/j.foodchem.2003.09.001

[16] Bigoniya, P., Nishad, R. and Singh, C.S. (2012) Preventive Effect of Sesame Seed Cake on Hyperglycemia and Obesity against High Fructose-Diet Induced Type 2 Diabetes in Rats. Food Chemistry, 133, 1355-1361. https://doi.org/10.1016/j.foodchem.2012.01.112

[17] Sarkis, J.R., Michel, I., Tessaro, I.C. and Marczak, L.D.F. (2014) Optimization of Phenolics Extraction from Sesame Seed Cake. Separation and Purification Technology, 122, 506-514. https://doi.org/10.1016/j.seppur.2013.11.036

[18] Koechner, W. (2013) Solid-State Laser Engineering. Springer, Berlin.

[19] Koechner, W. and Bass, M. (2006) Solid-State Lasers: A Graduate Text. Springer Science \& Business Media, Berlin.

[20] Shen, G., Rivers, M.L., Wang, Y. and Sutton, S.R. (2001) Laser Heated Diamond Cell System at the Advanced Photon Source for in Situ X-Ray Measurements at High Pressure and Temperature. Review of Scientific Instruments, 72, 1273-1282. https://doi.org/10.1063/1.1343867

[21] Sun, L. and Gong, K. (2001) Silicon-Based Materials from Rice Husks and Their Applications. Industrial \& Engineering Chemistry Research, 40, 5861-5877. https://doi.org/10.1021/ie010284b

[22] Lender, P.W. and Ruiter, R. (1990) Novel Inorganic Materials and Heterogeneous Catalysis. Inorganic and Metal-Containing Polymeric Materials. Plenum Press, New York, 187-195.

[23] Brinker, C.J. and Scherer, G.W. (2013) Sol-Gel Science: The Physics and Chemistry of Sol-Gel Processing. Academic Press, Cambridge.

[24] Kailasam, K., Epping, J.D., Thomas, A., Losse, S. and Junge, H. (2011) Mesoporous Carbon Nitride-Silica Composites by a Combined Sol-Gel/Thermal Condensation Approach and Their Application as Photocatalysts. Energy \& Environmental Science, 4, 4668-4674. https://doi.org/10.1039/c1ee02165f

[25] Li, B. and Cao, H. (2011) ZnO@ Graphene Composite with Enhanced Performance for the Removal of Dye from Water. Journal of Materials Chemistry, 21, 3346-3349. 
https://doi.org/10.1039/C0JM03253K

[26] Chen, J., Zhao, D., Jin, X., Wang, C., Wang, D. and Ge, H. (2014) Modifying Glass Fibers with Graphene Oxide: Towards High-Performance Polymer Composites. Composites Science and Technology, 97, 41-45.

https://doi.org/10.1016/j.compscitech.2014.03.023

[27] Sahoo, S., Seydibeyoğlu, M., Mohanty, A. and Misra, M. (2011) Characterization of Industrial Lignins for Their Utilization in Future Value Added Applications. Biomass and Bioenergy, 35, 4230-4237. https://doi.org/10.1016/j.biombioe.2011.07.009

[28] Bellamy, L.J. (1975) Amides, Proteins and Polypeptides. The Infra-Red Spectra of Complex Molecules. Springer, Berlin, 231-262.

https://doi.org/10.1007/978-94-011-6017-9_12

[29] Chang, Q., Hao, X. and Duan, L. (2008) Synthesis of Crosslinked Starch-Graft-Polyacrylamide-Co-Sodium Xanthate and Its Performances in Wastewater Treatment. Journal of Hazardous Materials, 159, 548-553.

https://doi.org/10.1016/j.jhazmat.2008.02.053 